\title{
APLIKASI PLTMH PENGHASIL ENERGI LISTRIK DI SUNGAI LAWANG DESA SIMBANG JAYA KECAMATAN BAHOROK
}

\author{
Eswanto $^{1}$, Satri JP Sitompul ${ }^{2}$, Tony Siagian $^{3}$, Iwan Gunawan ${ }^{4}$, Aminur $^{5}$ \\ ${ }^{1}$ Jurusan Teknik Mesin, Universitas Negeri Medan, Medan, Indonesia \\ ${ }^{2,3}$ Jurusan Teknik Mesin, Institut Teknologi Medan, Medan, Indonesia \\ ${ }^{4}$ Jurusan Teknik Mesin, Universitas Khairun, Ternate, Indonesia \\ ${ }^{5}$ Jurusan Teknik Mesin, Universitas Halu Oleo, Kendari, Indonesia \\ 1eswanto@unimed.ac.id, ${ }^{3}$ siagiantony@yahoo.com, ${ }^{4}$ giwangiwan@gmail.com, ${ }^{5}$ aminur@uho.ac.id
}

\begin{abstract}
ABSTRAK
Potensi energi berkelanjutan tanpa polusi di Indonesia harus terus dimanfaatkan, diantaranya adalah air sebagai tenaga penghasil listrik. Tidak tersedianya energi listrik khusunya daerah terpencil berdampak pada penyediaan energi nasional. Energi ramah polusi dan memiliki keunggulan dari berbagai sisi yaitu pembangkit listrik tenaga mikro hidro (PLTMH). Dalam penelitian ini aplikasi PLTMH dilakukan di lokasi Sungai Lawang Desa Simbang Jaya kecamatan bahorok. Tujuan penelitian ini adalah untuk mengetahui daya listrik yang dihasilkan PLTMH di Sungai Lawang. Metode penelitian yang dilakukan adalah studi lapangan, pembuatan PLTMH, pengujian dan aplikasi langsung PLTMH ke lokasi Sungai Lawang. Hasil penelitian aplikasi PLTMH secara langsung di Sungai Lawang Desa Simbang Jaya menunjukkan bahwa daya listrik terbesar yang dihasilkan oleh generator yaitu 1100,8 Watt dengan tegangan yang diperoleh sebesar 200 Volt sedangkan untuk kuat arus yang dihasilkan adalah 5,5 Amper. Memperhatikan dari data-data hasil keluaran PLTMH yang telah diperoleh di Sungai Lawang, dapat disimpulkan bahwa energi dalam bentuk daya listrik tersebut dapat digunakan masyarakat sekitar Sungai Lawang dalam memenuhi kebutuhan listrik, seperti untuk memasak, lampu penerangan jalan dan menghidupkan mesin bor tangan.
\end{abstract}

Kata kunci: PLTMH, Sungai Lawang, energi listrik, daya, turbin, generator.

\section{ABSTRACT}

\section{Application of PLTMH Producing Electrical Energy In Lawang River Simbang Jaya Village of}

Bahorok Districts. The potential for sustainable energy without pollution in Indonesia must continue to be utilized, but it is hoped that it can be used as electricity generation. The not availability of electrical energy is especially the transfer of the region to the supply of national energy. Friendly energy reserves and has advantages from various sides, namely micro hydro power plants (PLTMH). In this research, the application of PLTMH was conducted at the location of Lawang River, Simbang Jaya Village, Bahorok District. The purpose of this research is to study the electric power generated PLTMH in Lawang River. The research methods carried out were field studies, making PLTMH, testing and direct application of PLTMH to the location of Lawang River. The results of the research on PLTMH applications directly into Lawang River, Simbang Jaya Village, showed that the electric power generated by the generator was a 1100.8 Watt with a voltage obtained 200 Volts, while the current generated power was 5.5 Ampere. Taking into account the data of the PLTMH output obtained in the Lawang River, it can deny the energy into electricity that can be used by the community around the Lawang River to meet electricity needs, such as for cooking, street lighting and turning on a hand drill machine.

Keywords: PLTMH, Lawang River, electrical energy, micro hydro, turbine, generator.

\section{PENDAHULUAN}

Pada saat sekarang ini sumber energi alternatif menjadi pilihan utama bagi pengembangan energi berkelanjutan disemua negara, dimana energi tersebuat dapat berasal dari air. Sumber air yang ada dan mengalir maupun dari air jatuh akibat potensial energi menjadi pilihan dalam pengembangan sistem tenaga terbarukan penghasil listrik ramah polusi. Sebagaimana diketahui bahwa pada sebuah air yang mengalir seperti sungai terdapat energi potensial dan energi kinetik di dalamnya. Sumber tenaga air 
merupakan asimilasi dari air yang mengalir akibat gaya dorong permukaan bersumber dari hulu. Dalam mengaplikasikan energi air sebagi pembangkit daya listrik ramah polusi, sesungguhnya yang digunakan adalah dalam bentuk energi mekanis dan energi listrik dalam aplikasi tertentu. Dalam instalasinya alternatif energi air menggunakan kincir air atau turbin air dengan air terjun atau aliran air di Sungai yang konstan sebagai sumber tenaga utama [1]. Di daerah Desa Simbang Jaya Kecamatan Bahorok Sumatera Utara memiliki potensi energi air, dimana desa ini memiliki banyak aliran Sungai dengan beberapa diantaranya dibuat bercabang untuk mengaliri sawah warga, dimana air tersebut berasal dari gunung lauser sebagai sumber utama mata air yang dapat dimanfaatkan dan dijadikan sebagai sistem tenaga listrik pedesaan. Keunggulan Sungai ini, air yang mengalir kondisinya konstan. Dalam kaitannya dengan potensi dimaksud adalah Sungai Lawang di Desa Simbang Jaya yang dapat dijadikan atau tempat aplikasi penerapan pembangkit listrik tenaga mikro hidro (PLTMH) dalam menyediakan kebutuhan listrik.

Pembangkit listrik tenaga mikro hidro (PLTMH) sebagai pembangkit listrik berukuran kecil dimana tenaga penggeraknya adalah air baik itu saluran air persawahan/irigasi, aliran Sungai yang tetap, dan air terjun dengan memanfaatkan potensial ketinggian sumber air dan debit airnya. Pada sistem pembangkit mikro hidro energi listrik didapat dari berbagai bentuk konstruksi aliran sungai dengan debit standar tertentu atau yang memiliki perbedaan ketinggian dengan model sistem jatuh air [2]. Jika diperhatikan secara teknik bahwa semakin tinggi jenis jatuhnya air maka yang terjadi pula semakin besar energi potensial air yang didapat dan diubah menjadi energi listrik. Secara teknis komponen utama yang di miliki PLTMH yaitu berupa air sebagai sumber tenaga penggeraknya, turbin dan generatornya sebagai pembangkit energi listriknya, dimana komponen tersebut mudah didapat [3].

Mikro Hidro merupakan istilah yang digunakan untuk sebuah rangkaian penuh dalam instalasi pembangkit listrik yang menggunakan energi air sebagai sumber tenaga penggerak utama. Kondisi air mengalir yang dapat dimanfaatkan sebagai sumber tenaga penghasil output listrik adalah yang memiliki kapasitas aliran danhead tertentu. Semakin besar kapasitas aliran air maupun tinggi jatuh air dari instalasi PLTMH, maka semakin besar juga energi yang bisa dimanfaatkan untuk menghasilkan energi listrik dari sistem tersebut [4]. Dalam prakteknya, biasanya mikro hidro dibangun berdasarkan situasi bahwa adanya aliran air yang mengalir di suatu daerah dengan kapasitas dan ketinggian yang cukup dan memenuhi standar untuk dapat diaplikasikan pada sintem pembangkit listrik tenaga air. Pengertian kapasitas merujuk pada jumlah volume aliran air persatuan wakttu, sedangan selisih ketinggian aliran air sampai ke instalasi diterapkannya mikro hidro disebut dengan head tepasang [5] [6].

Instalasi dan komponen utama PLTMH memiliki konstruksi yang sederhana, mudah dioperasikan, mudah dalam perawatan serta dengan biaya investasi yang terjangkau sehingga menjadi pilihan tepat untuk diterapkan kembangkan sebagai pilihan pertama sistem energi pembangkit listrik secara berkelanjutan ramah polusi. Satu diantara komponen penting pada sistem mikro hidro adalah sudu turbin, dimana bagian ini dapat mempengaruhi energi kinetik yang dihasilkan dan performance PLTMH secara keseluruhan. Untuk itu perlu dilakukan penelitian lebih lanjut tentang sudu turbin tehadap kinerja PLTMH terpasang [7].

Pemilihan sistem PLTMH jika di runut dari sisi teknologi dipilih karena mempunyai konstruksi dan bentuk instalasi yang sangat sederhana, pengoperasian tidak rumit, suku cadang komponen mudah didapat, pemeliharaan tidak susah. Kemudian ditinjau secara ekonomi, biaya operasional dan perawatannya relatif murah sedangkan biaya investasinya cukup bersaing dengan pembangkit listrik lainnya yang berasal dari fossil dan gas [8].

Pemenuhan sumber energi alternatif di seluruh dunia untuk mencukupi ketersediaan energi listrik selalu mengalami kenaikan pertahunnya. Indonesia, merupakan negara yang sumber energi alternatifnya melimpah, namun ketersediaan untuk pemenuhan pembangkit listrik masih jauh dari cukup. Situasi ini mengakibatkan beberapa wilayah belum terkoneksi listrik seperti daerah lainnya [9][10][11]. Jika diperhatikan dari segi potensi energi air di Indonesia sangat melimpah, oleh sebab itu sebuah pembangkit listrik layak diterapkan untuk mencukupi kebutuhan 
pasokan listrik di daerah perkampungan yang belum terjangkau oleh listrik pemerintah. Sebuah PLTMH memiliki beberapa keunggulan yang membuatnya menjadi pilihan utama dalam penerapan energi berkelanjutan, yaitu: dalam hal tenaga penggerak pada PLTMH berupa air dari alam tidak akan habis atau berubah menjadi bentuk lain, dalam segi biaya pengoperasian, produksi dan perawatannya murah serta mudah, saat beroperasi dapat dihentikan setiap waktu tanpa melalui prosedur yang rumit, sistem PLTMH sangat sederhana tetapi banyak keunggulan, komponen alat pembuat PLTMH mudah diperoleh dan memiliki ketangguhan yang baik, sehingga dapat diandalkan, PLTMH tidak memberikan dampak yang besar terhadap ekologi di sekitarnya karena ramah lingkungan, hal ini berbeda dengan sumber pembangkit yang berasal dari fossil seperti batubara,solar dan lainnya [12].

Dalam kenyataannya pembuatan instalasi PLTMH sebagai sistem pembangkit daya untuk penghasil listrik desa, banyak sekali faktor-faktor yang harus diperhatikan supaya dalam pembangunan PLTMH hasilnya dapat dimanfaatkan secara optimal dan tidak sia-sia oleh msyarakat pemakai aplikasi PLTMH. Dalam mendukung tercapainya penerapan PLTMH perlu dilakukan perencanaan yang matang dengan didasarkan pada hasil studi kelayakan awal sebagai kelanjutan studi terhadap potensi alam dan sumber daya setempat yang mencakup sumber daya air sebagai tolak ukur utama, serta sumber daya alam dan makhluk hidup disekitaran akan dibautnya PLTMH. Keakuratan dan ketepatan kajian data hasil studi kelayakan secara nyata dan autentik akan dapat menentukan keberhasilan suatu pembangunan peralatan PLTMH terpasang. Studi kelayakan dan desain teknik juga tidak kalah pentingnya dalam mendukung aplikasi PLTMH, dimana hal ini dapat meliputi desain teknis bangnan sipil dan sistem elektro-mkanikal, sistem kontrol mekanis atau otomatis, sistem ransmisi elektrikal,distribusi tegangan tinggi hingga analisis keuangan dan desain penyiapan kelembagaan PLTMH dari perencanaan sampai terpasang [13]. Penentuan desain teknis mesti dilakukan tepat dan akurat, dengan menrapkan teknologi yang teruji agar pembangkit listrik mempunyai kinerja yang memuaskan, sebagai implementasi dari peralatan utama dan pendukung [14], misalnya pada sistem kontrol menggunakan pengaturan beban sehingga jumlah output daya generator selalu sama dengan beban, dan jaringan distribusi listrik dirancang menggunakan kawat penghantar dengan inti tembaga berisolasi PVC dan selubung luar berbahan PVC, dengan tiang berupa kayu [15].

Tujuan penelitian ini secara umum adalah menerapkan PLTMH yang di dibuat di Sungai Lawang Desa Simbang Jaya kecamatan bahorok untuk menghasilkan energi listrik berskala rumah tangga yang dapat digunakan sebagai sumber energi listrik untuk membantu masyarakat Desa Simbang Jaya yang sulit mendapatkan arus listrik. Dengan adanya PLTMH yang di Sungai Lawang Desa Simbang Jaya, maka berikutnya masyarakat dapat membuat dan menerapkan secara mandiri dari beberapa pecahan Sungai Lawang yang lain.

\section{METODE}

Dalam penerapan PLTMH ini dilakukan secara terencana dan terstruktur, agar dapat diperoleh hasil yang baik dengan tahapan-tahapan:

a). Surve ke lokasi Sungai Lawang

Surve dilakukan untuk mendapatkan informasi lokasi pecahan aliran air Sungai Lawang yang mempunyai potensi untuk diaplikasikannya sistem PLTMH, mengingat lokasi tersebut daerah wisata nasional.

b). Studi kelayakan Sungai Lawang

Bagian ini dilakukan untuk menggali sisi teknis, masyarakat dan ekologi terhadap yang ditimbulkan saat aplikasi PLTMH.

c). Desain PLTMH

Desain disiapkan sebagai bagian dari persiapan pebuatan komponen sistem PLTMH diantaranya tipe turbin, tipe sudu, desain bangian sipil, mekanikal, jaringan listrik output PLTMH.

d). Penyiapan PLTMH

Persiapan awal sampai akhir penting dibuat secara terukur sehingga kegiatan di Desa Simbang Jaya bisa berjalan lancar, yaitu seperti pembuatan keseluruhan sistem PLTMH, persiapan material dan persiapan personil.

e). Pembangunan dan Aplikasi PLTMH Bagian ini merupakan instalasi lengkap dan pemasangan seluruh sistem komponen PLTMH di Sungai Lawang.

f). Pelatihan dan sosialisasi 
Sebagai pengenalan pada masyarakat Desa Simbang Jaya tentang sistem PLTMH, proses ini dilakukan pada awal kegiatan dan akhir kegiatan aplikasi sistem PLTMH yang nantinya masyarakat dapat memanfaatkannya sendiri di pecahan sungai yang lain.

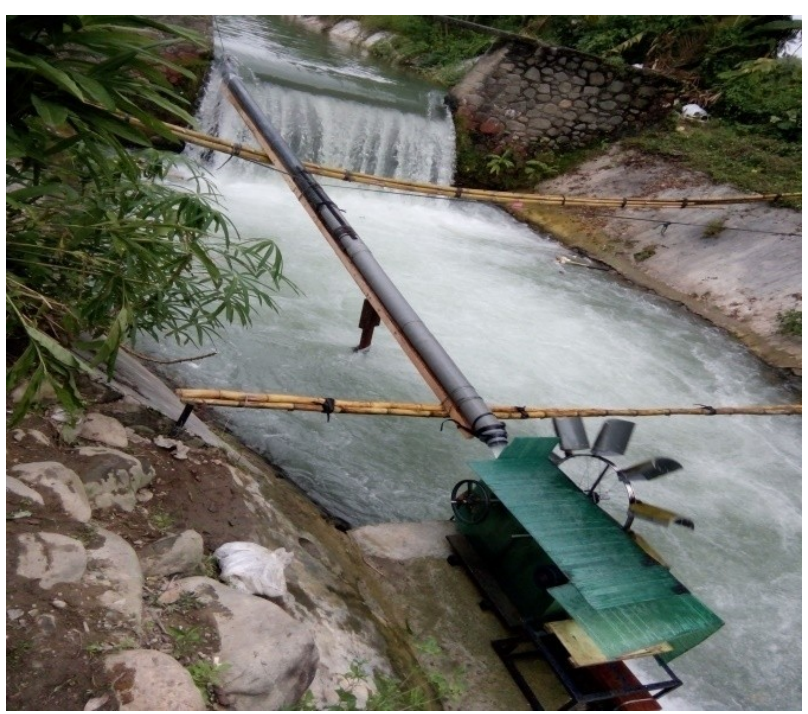

Gambar 1. Lokasi aplikasi PLTMH Sungai Lawang

Gambar 1 adalah lokasi dilakukan aplikasi pembangunan PLTMH. Tinggi jatuh efektif didapat dengan mengurangkan tinggi jatuh total dengan losses ketinggian pada saluran air. Ketinggian jatuh merupakan tinggi air yang bekerja normal pada bagian turbin yang sedang beroperasi. Pada tipe saluran air, jika diketahui bagian muka air pada bangunan PLTMH dan saluran bawah serta debit air yang mengalir, maka ketinggian jatuh efektif dapat hitung yaitu berdasarkan biaya konstruksi paling murah dengan memperhatikan slope dimensi penampang saluran air, dan luasan penampang pipa. Parameter dan bagian utama dari turbin Pelton dapat ditentukan dengan persamaan berikut [16] [17] [18]:

- Debit air yang masuk ke pipa pesat dapat ditentukan dengan persamaan 1, yaitu:

$$
Q=\frac{V}{t}
$$

dimana:

$$
\begin{aligned}
& \mathrm{Q}=\text { debit air }\left(\mathrm{m}^{3} / \mathrm{s}\right) \\
& \mathrm{V}=\text { volume tabung ukur }\left(\mathrm{m}^{3}\right) \\
& \mathrm{t}=\text { waktu }(\mathrm{s})
\end{aligned}
$$

- Untuk menentukan kecepatan pancaran jet yang keluar nozel dihitung menurut persamaan 2 :

$$
Q=\frac{V}{A_{n}}
$$

dimana:

$$
\begin{aligned}
& \mathrm{Q}=\text { kapasitas aliran }\left(\mathrm{m}^{3} / \mathrm{s}\right) \\
& \mathrm{A}_{\mathrm{n}}=\text { luaas penampang nozel }\left(\mathrm{m}^{2}\right) \\
& \mathrm{V}=\text { kecepatanpancaran nozel }(\mathrm{m} / \mathrm{s})
\end{aligned}
$$

- Untuk kecepatankeliling turbin $\omega(\mathrm{m} / \mathrm{det})$ dapat dihitung menurut persamaan 3 .

$$
\omega=\frac{2 \pi n}{60}
$$

dimana : $\omega=$ kecepatan keliling turbin $(\mathrm{m} / \mathrm{det})$

$$
\mathrm{n}=\text { putaran turbin (rpm) }
$$

- Terkait dengan besarnya torsi dapat dihitung dengan menggunakan persamaan 4 .

$$
T=F \times L
$$

dimnana :

$$
\begin{aligned}
& \mathrm{T}=\operatorname{torsi}(\mathrm{Nm}) \\
& \mathrm{F}=\operatorname{gaya}(\mathrm{N}) \\
& \mathrm{L}=\text { jari-jari turbin }(\mathrm{m})
\end{aligned}
$$

Sedangkan untuk daya, dilakukan perhitungan untuk berbagai jenis daya yaitu:

a). Daya hidroliis yang masuk nozel ditentukan berdasarkan persamaan 5, yaitu:

$$
P_{h}=\rho \times \mathrm{g} \times Q \times H
$$

dimana :

$$
\begin{aligned}
\mathrm{P}_{\mathrm{h}}= & \text { daya hidrolis masuk ke nozel (Watt) } \\
\rho= & \text { massa jenis air } \left.\left(996,74 \mathrm{~kg} / \mathrm{m}^{3}\right)\right) \\
\mathrm{g}= & \text { gravitasi }\left(\mathrm{m} / \mathrm{s}^{2}\right) \\
\mathrm{Q}= & \text { kapasitasaliran }\left(\mathrm{m}^{3} / \mathrm{s}\right) \\
\mathrm{H}= & \text { head }(\mathrm{m}) \\
& \text { (head diukur sebelum masuk nozel) }
\end{aligned}
$$

b). Daya kinetik pancaran jet air dapat diselesaikan mengunakan persamaan 6 .

$$
P_{k}=\frac{1}{2} \rho A_{n} V^{3}
$$

dimana :

$$
\begin{aligned}
& \mathrm{P}_{\mathrm{k}}=\text { daya kinetik pancaran air } \\
& \rho=\text { massa jenis air }\left(996,74 \mathrm{~kg} / \mathrm{m}^{3}\right) \\
& \mathrm{An}_{\mathrm{n}}=\text { luasan saluran pipa }\left(\mathrm{m}^{2}\right) \\
& \mathrm{V}^{3}=\text { kecepatanaliran air }(\mathrm{m} / \mathrm{s})
\end{aligned}
$$

c). Daya turbin terpasang dihitung mengunakan persamaan 7 .

$$
P_{t}=T \times \omega
$$

dimana :

$$
\begin{aligned}
& \mathrm{T}=\text { torsi }(\mathrm{Nm}) \\
& \omega=\text { kecepatan keliling turbin }(\mathrm{m} / \text { det })
\end{aligned}
$$

- Torsi merupakan bagian penting untuk diketahui, dimana torsi dapat dicari menurut persamaan 8 .

$$
T=F \times I
$$

dimana :

$$
\begin{aligned}
& \mathrm{F}=\operatorname{gaya}(\mathrm{N}) \\
& \mathrm{I}=\text { jari jari turbin }(\mathrm{m})
\end{aligned}
$$

- Perhitungan daya generator dapat dilakukan menurut persamaan 9 . 


$$
P_{\mathrm{g}}=V \times I \times \operatorname{Cos} \varphi
$$

dimana :

$$
\begin{aligned}
& \mathrm{P}_{\mathrm{g}}=\text { daya generator (Watt) } \\
& \mathrm{V}=\text { tegangan output generator (Volt) } \\
& \mathrm{I}=\text { arus output generator (Amper) } \\
& \operatorname{Cos} \varphi=1.0 \text { (untuk generator) }
\end{aligned}
$$

- Dalam perhitungan Efisiensi dilakukan untuk mengetahui efisiensi sudu turbin ( $\eta \mathrm{t}$ ) yang dapat dihitung menurut persamaan 10 .

$$
\eta_{t}=\frac{P_{t}}{P_{k}} x 100 \%
$$

dimana :

$$
\begin{aligned}
& \eta t=\text { efisiensi sudu turbin }(\%) \\
& \mathrm{P}_{\mathrm{t}}=\text { daya turbin }(\text { Watt }) \\
& \mathrm{P}_{\mathrm{k}}=\text { daya kinetik jet air }(\mathrm{Watt})
\end{aligned}
$$

\section{HASIL DAN PEMBAHASAN}

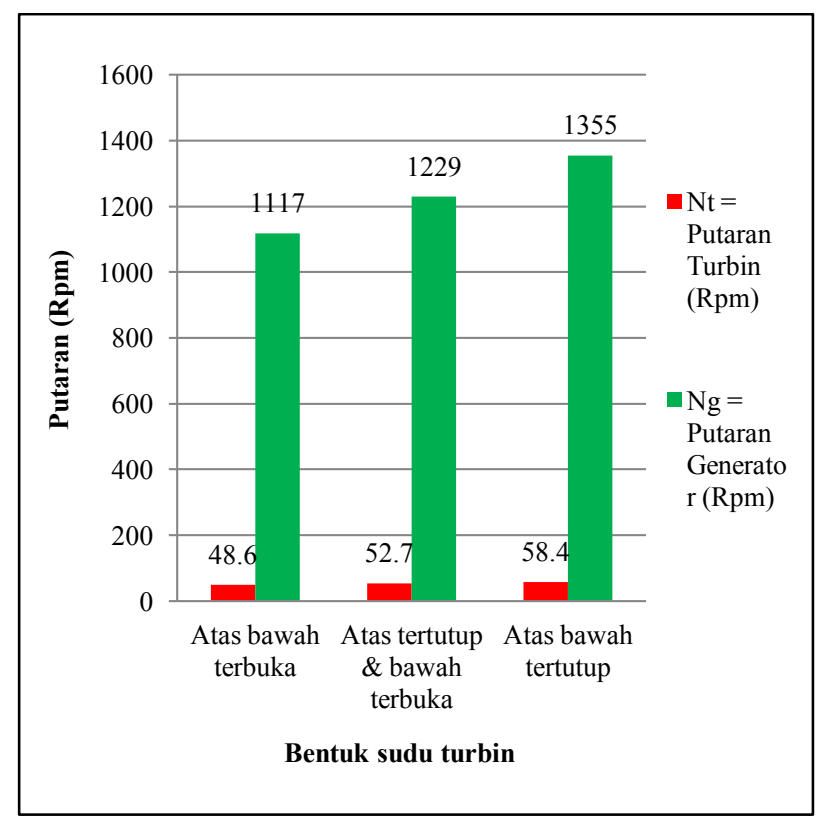

Gambar 2. Grafik hubungan bentuk sudu dan putaran (turbin, generator)

Data hasil penelitian yang telah lakukan di Sungai Lawang Desa Simbang Jaya kecamatan bahorok dalam rangka pembuatan pembangkit listrik tenaga mikro hidro (PLTMH) telah diperoleh dengan hasil pengukuran. Selanjutnya dilakukan pengolahan data dan kemudian dituangkan dalam bentuk grafik agar mudah memberikan analisa pembahasannya. Pada gambar 2 adalah grafik hubunganantara bentuk sudu turbiin dengan putaran. Putara yang dimaksud dalam gambar 2 adalah putaran pada turbin air dan putaran yang terjadi pada generator listrik. Pada gambar 2 dapat dilihat bahwa nilai putaran turbin pada sudu 10 bentuk model sudu atas bawah terbuka dengan hasil pengukuran dan perhitungan diperoleh putaran turbin 48,6 rpm sedangkan untuk debit aliran 46,019 liter/detik. Dari penomena tersebut diketahui bahwa pengaruh putaran turbin memberikan dampak yang sangat signifikan yaitu pada saat air menekan sudu sudu turbin, sehingga air tersebut tidak terlalu sepenuhnya menekan sudu turbin karena air yang berada dalam sudu yang terbuka bagian atas dan bawah tersebut beberapa diantaranya telah tumpah akibat dari tidak tertampungnya air pada sudu-sudu tersebut, yang menyebabkan putaran yang dihasilkan turbin tidak terlalu besar. Dibagian lain yaitu putaran generator yang diperoleh adalah $1117 \mathrm{rpm}$, hasil dari data putaran tersebut didukung oleh adanya bantuan daya transmisi yang dilakukan yaitu perbandingan jumlah roda gigi dengan empat tingkat perbandingan sehingga yang terjadu antara putaran turbin dengan putaran generator yaitu 1: 23 putaran. Kondisi tersebut sedikit berbeda dengan apa yang telah disampaikan oleh penelitian Parabelem, terkait dengan penelitian PLTMH di aliran Sungai Ongak yang menyatakan bahwa ketika aliran air di arahkan ke bagian sudu-sudu turbin yang terpasang, maka akan mengakibatkan poros turbin menjadi berputar. Dalam hal ini putaran yang terjadi pada poros turbin diteruskan untuk memutar generator, sehingga menghasilkan listrik dan dapat dimanfaatkan untuk sumber energi. Dalam kenyataannya masih yang disampaikan oleh Parabelem bahwa dalampenentuan dimensi dan jumlah sudu turbin merupakan hal yang harus menjadi perhatian khusus, karena memberikan dampak terhadap output yang diperoleh [2].

Pada bentuk model sudu bagian atas tertutup dan bagian bawah terbuka putaran turbin yang diperoleh sebesar 52,7 rpm dengan cara yang sama dan juga debit yang sama pengaruhnya mengapa lebih tinggi putaranya dari bentuk sudu atas bawah terbuka. Jawabannya adalah karena pada saat air menumbuk sudu turbin air tersebut, air masih bisa ditahan oleh bagian ujung-ujung sudu walaupun dalam hal ini kondisinya tidak sepenuhnya tertahan karena bagian atas sudu-sudu tersebut posisinya tertutup. Dari pengamatan yang telah dilakukan secara visual lapangan atau pengamatan secara langsung terlihat bahwa pada putaran generatornya secara spontan terjadi kenaikan yang sangat siknifikan, sehinggay didapat putaran generator listrik sebesar $1229 \mathrm{rpm}$. 
Pada kondisi bentuk kontruksi lain yaitu bentuk model sudu atas bawah posisi tertutup diperoleh putaranya lebih tinggi dari pada bagian atas dan bawah terbuka dan bagian atas tertutup dan bagian bawah terbuka dengan debit yang sama dan cara yang sama putaran turbin yang diperoleh $58,4 \mathrm{rpm}$, mengapa demikian karena pada air menekan sudu turbin tersebut tekananya lebih tingga dibandingkan percobaan 1 dan ke 2 karena air yang berada dalam sudu tersebut masih banyak yang tertampung, tidak langsung terbuang karena pada bagian atas bawah sudu turbin tersebut posisi tertutup sehingga putaranya lebih tinggi yang menyebabkan putaran generatornya juga akan naik. Pada gambar 2 memperlihatkan dan menginformasikan bahwa hasil pengujian dan penerapan yang telah dilakukan di Sungai Lawang Desa Simbang jaya layak sebagai sumber energi, dimana putarannya didapat sebesar $1355 \mathrm{rpm}$. Dengan cara yang sama hasil pengukuran yang dilakukan dapat disimpulkan bahwa nilai putaran turbin dan putaran generator paling tertinggi yaitu berada pada jumlah sudu 10 bagian atas bawah tertutup dengan putaran turbin 58,4 rpm, dan putaran generator sebesar $1355 \mathrm{rpm}$. Dari pembahasan tersebut sebenatnya telah dapat diperoleh perbandingannya dengan yang telah diperoleh oleh murni dkk, bahwa dengan model sudu standar putaran turbin bisa mencapai 48,5 rpm [3].

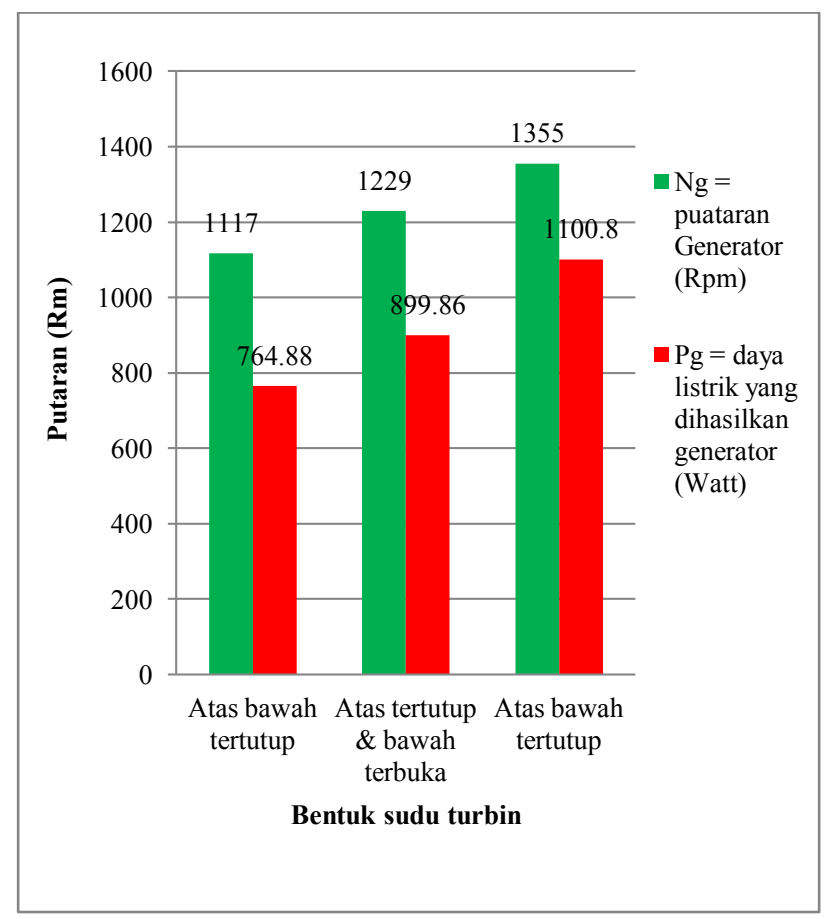

Gambar 3. Bentuk sudu dengan putaran generator $(\mathrm{Ng})$ dan daya yang dihasilkan generator $(\mathrm{Pg})$.

Pada diagram batang gambar 3 dapat kita lihat bahwa nilai putaran generator pada sudu 10 bentuk model sudu atas bawah terbuka putaran generator yang sudah diperbesar dengan daya transmisi dengan perbandingan putaran yang dibuat 1:23 putaran dengan empat tingkat jumlah roda yang dibuat maka putaran yang diperoleh generator 1117 rpm dan daya listrik yang diperolehh generator yaitu 764,88 Watt. Pada waktu bentuk percobaan aplikasi model sudu bagian atas tertutup dan bagian bawah terbuka dengan cara yang sama, putaran generator yang sudah diperbesar oleh daya transmisi yang telah dibuat maka putaran generator diperoleh sebesar $1229 \mathrm{rpm}$ dengan besarnya daya listrik yang dihasilkan adalah 899,86 Watt, sedangkan pada sisi lain yaitu percobaan bentuk model sudu atas bawah posisi tertutup dengan cara yang sama putaran generator yang sudah diperbesar oleh daya transmisi yang dibuat maka putaran yang diperoleh sebesar $1355 \mathrm{rpm}$, dengan daya listrik yang dihasilkan 1100,8 Watt. Keterangan akhir dari data pada gambar 3 hasil pengukuran yang didapat, telah disimpulkan bahwa nilai putaran generator dan daya turbin air paling tertinggi yaitu berada pada jumlah sudu 10 bagian atas bawah tertutup denganputaran generator yang dihasilkan $1355 \mathrm{rpm}$, dan dayayang dihasilkan generator sebesar 1100,8 Watt, situasi itu menandakan pada jumlah sudu 10 yang paling efektif untuk penerapan di Sungai Lawang. 


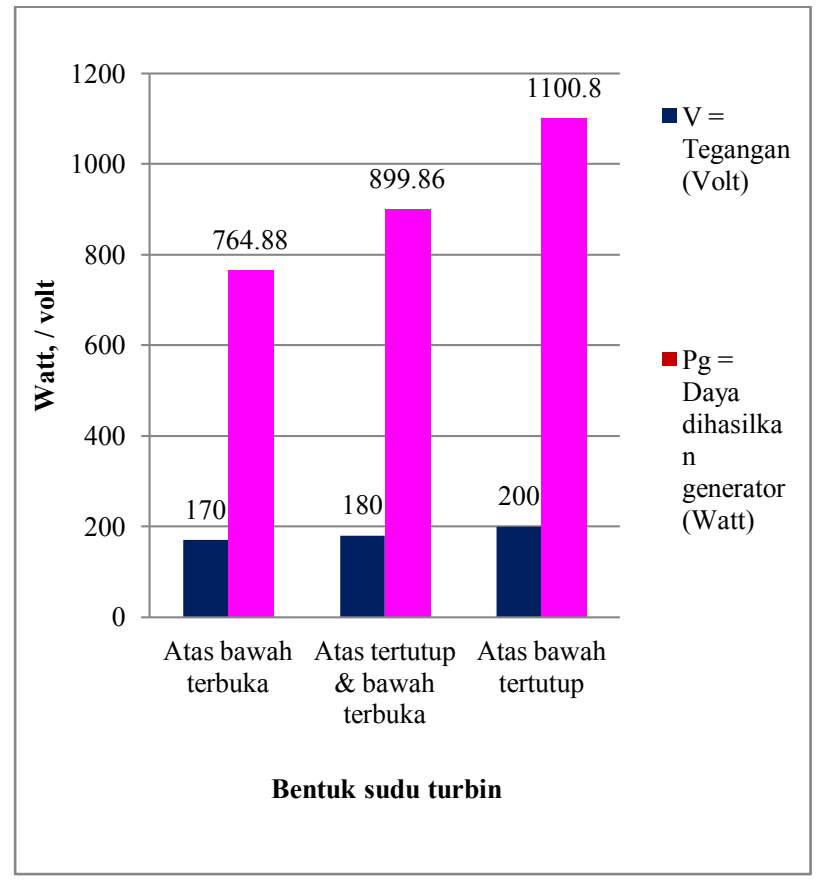

Gambar 4. hubungan bentuk sudu dengan tegangan (v) dandaya listrik yang dihasilkan generator.

Aplikasi PLTMH yang telah dilakukan memberikan dampak positif bagi masyarakat sekitar Sungai Lawang, karena dapat memberikan tambahan pasokan energi. Pada gambar 4 dapat kita lihat bahwa tegangan pada sudu 10 bentuk model sudu atas bawaah terbuka tegangan yang diperoleh 170 Volt sedangkan dayalistrik yang didapat generator yaitu 764,88 Watt kondisi ini diakibatkan bentuk model sudu atas bawah terbuka putaran turbin yang dihasilkan tidak terlalu besar sehingga putaran generatornya kecil, begitu juga tengangan dan daya listrik yang dapat dihasilkan generator tersebut lebih kecil dibandingkan dengan yang dihasilkan pada bentuk model sudu bagian atas tertutup dan bagian bawah terbuka. Pada posisi bentuk model sudu bagian atas tertutup dan bagian bawah terbuka, tegangan yang diperoleh generator 180 Volt dan daya listrik yang diperoleh generator 899,86 Watt, lebih besar dari pada model sudu bagian atas bawah terbuka megapa demikian karena putaran turbin dan putaran generator pada saat posisi sudu turbin bagian atas tertutup bagian bawah terbuka lebih besar, sedangkan pada bentuk model sudu atas bawah posisi tertutup tengangan yang diperoleh generator 200 Volt dengan daya listrik yang dihasilkan 1100,8 Watt. Pada posisi sudu turbin atas bawah tertutup karena putaran turbin dan putaran generator yang dihasilkan lebih besar dari pada percobaan 1 dan 2 . Dari data hasil pengukuran yang didapat maka didapat kesimpulan bahwa nilai tegangan generator paling tertinggi yaitu berada pada sudu 10 bagian atas bawah tertutup dengan tegangan yang dihasilkan adalah 200 volt, dan daya yang diperoleh generator sebesar 1100,8 Watt.

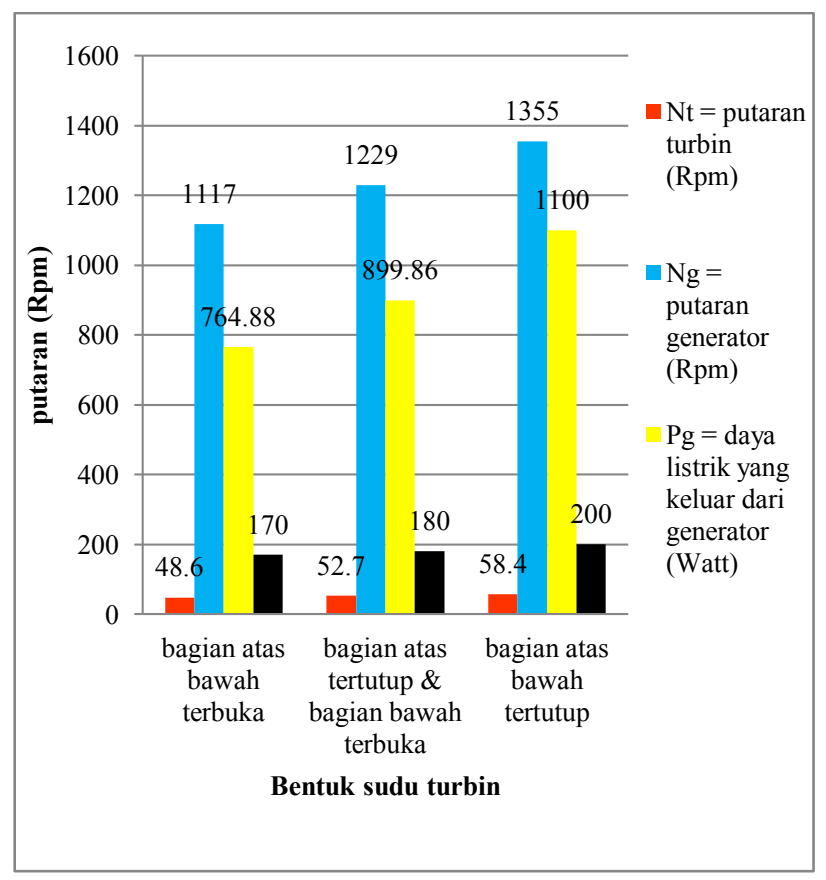

Gambar 5. Grafik hubungan bentuk sudu turbin terhadap $\left(\mathrm{N}_{\mathrm{t}}\right),\left(\mathrm{N}_{\mathrm{g}}\right),\left(\mathrm{P}_{\mathrm{g}}\right)$, dan $(\mathrm{V})$.

Pada gambar 5 dapat kita lihat bahwa nilai putaran turbin pada sudu 10 bentuk model sudu atas bawah terbuka putaran turbin yang diperoleh $48,6 \mathrm{rpm}$ dan putaran generator yang diperoleh $1117 \mathrm{rpm}$, hal ini disebabkan adanya bantuan daya transmisi yang dilakukan yaitu perbandingan jumlah roda gigi dengan empat tingkat perbandingan sehingga antara putaran turbin dengan putaran generator yaitu 1: 23 putaran dengan debit aliran diperoleh 46,019 liter/detik. Pengaruh putaran turbin yang dihasilkan karena pada saat air menendang sudu sudu turbin, air tersebut tidak terlalu sepenuhnya menekan sudu turbin karena air yang berada dalam sudu yang terbuka bagian atas dan bawah tersebut telah bertumpahan jadi putaran yang dihasilkan turbin tidak terlalu besar dan dayalistrik yang dihasilkan generator 764,88 Watt, dan tegangan yang diperoleh 170 Volt. Pada bentuk model sudu bagian atas tertutup dan bagian bawah terbuka putaran turbin yang diperoleh 52,7 rpm lebih tinggi dibandingkan 
pada saat model sudu bagian atas bawah terbuka, kondisi ini disebabkan karena pada saat air menumbuk sudu turbin tekanannya lebih tinggi karena air yang berada pada sudu turbin tidak langsung terbuang semuanya. Dari hasil pengukuran secara langsung di Sungai Lawang diperoleh putaran generator adalah $1229 \mathrm{rpm}$, dayalistrik yang didapat generator 764,88 Watt, dan tegangan yang diperoleh yaitu 180 Volt sedangkan pada bentuk model sudu atas bawah posisi tertutup putaran turbin yang diperoleh 58,4 rpm lebih tinggi dari pada posisi model sudu bagian atas bawah terbuka dan bagian atas tertutup, bawah terbuka. Kondisi ini disebabkan karena pada saat debit air menendang sudu turbin tekanan air lebih tinggi karena pada posisi bentuk model sudu atas bawah tertutup otomatis air yang menumbuk sudu turbin tersebut tidak langsung tumpah karena ditampung sudu tersebut, sehingga dorongan air otomatis relatif besar untuk memutar turbin.

Dari data hasilpengukuran yang telah dilakukan pada PLTMH didapat putaran turbin sebesar 58,4 rpm dan putaran generator yaitu $1355 \mathrm{rpm}$, daya listrik yang diperoleh yaitu 1100,8 Watt sedangkan tegangan yang dihasilkan sebesar 200 Volt. Dari penjelasan dan analisa data yang telah dilakukan terkait dengan aplikasi PLTMH dapat disimpulkan bahwa nilai putaran turbin dan putaran generator paling tertinggi yaitu berada pada model sudu 10 bagian atas bawah tertutup dengan putaran turbin 58,4 rpm, dan putaran generator yang dihasilkan $1355 \mathrm{rpm}$, dan daya listrik yang dihasilkan generator 1100,8 Watt, atau kurang lebih $1 \mathrm{~kW}$, dan tegangan yang dihasilkan 200 Volt. Penerapan PLTMH ini memberikan informasi secara akademik bahwa penentuan model sudu memberikan dampak yang sangat signifikan terhadap perolehan daya dan putaran akhir proses dan secara umum adalah hasil perormance sistem pembangkit mikro hidro yang telah diaplikasikan di Sungai Lawang.

\section{KESIMPULAN}

Pengaplikasian pembangunan PLTMH di Sungai Lawang telah dilakukan dan memberikan dampak yang baik bagi masrakat sekitar, terutama dalam hal pemenuhan energi listrik. Dari hasil pengujian dan pengukuran yang dilakukan secara langsung di lokasi Sungai Lawang Desa Simbang Jaya diperoleh putaran turbin dan putaran generator tertinggi yaitu berada pada model jumlah sudu 10 dengan bagian atas dan bawah tertutup, sedangkan untuk daya listrik dihasilkan sebesar 1100,8 Watt, dengan tegangan yang sebesar 200 Volt sedangkan kuat arus yang dihasilkan adalah 5,5 Amper. Dari data tersebut dapat disimpulkan bahwa daya yang dihasilkan dapat digunakan oleh masyarakat untuk mendapatkan energi listrik skala rumah tangga untuk memenuhi kebutuhan sehari hari. Energi listrik yang dimaksud dan telah diaplikasikan adalah untuk mengisi ulang daya aki mobil, lampu led Luxen 30 Watt sebanyak 4 lampu yang dipasang untuk menerangi jalan dan salah satu rumah masyarakat, 1 (satu) mesin gerinda tangan daya 600 Watt dan mesin bor tangan GSB 550 dan juga diterapkan pada rice cooker untuk memasak nasi. Dari beberapa peralatan tersebut diterapkan secara bergantian menyesuaikan dengan daya listrik yang diperoleh PLTMH Sungai Lawang.

\section{DAFTAR PUSTAKA}

[1] A.Rifat and I.Mahzuba, A Case Study and Model of Micro Hydro Power Plant Using the Kinetic Energy of Flowing Water of Surma and Meghna Rivers of Bangladesh, The International Journal Of Science \& Technology volume-2, issue-1. pp 87-95, 2014.

[2] T.D. R Parabelem, Analisis Pembangkit Listrik Tenaga Mikro Hidro (PLTMH) Pada Daerah Aliran Sungai Ongkak Mongondow di Desa Muntoi Kabupaten Bolaang Mongondow. Jurnal Penelitian Saintek, Vol. 16, no.2, pp.160-171, 2011.

[3] S. Murni, J. Whale, T. Urmee, J. Davis, D. Harries, "The Implementation of Micro Hydro Projects in Remote Villages on the Border of Indonesia and Malaysia: Lessons Learnt", International Conference and Utility Exhibition 2014 on Green Energy for Sustainable Development (ICUE 2014), Pattaya City, Thailand, 2014.

[4] H. Nugroho, Sunaryo. "Evaluation of MicroHydro Power Operation in Wangan Aji, Wonosobo Regency", PPKM Journal, vol. II, pp. 137-143, 2014.

[5] B. J, Sinaga, Perancangan turbin air untuk sistem pembangkit listrik tenaga mikro hidro (Studi kasus Desa Way Gison Kecamatan 
Sekincau Kabupaten Lampung Barat). J. Sains dan Inovasi, Vol 1, no. 5, pp.64-75, 2009.

[6] Eswanto., D.Syahputra, Analisa Distribusi Kapasitas Aliran Fluida Di Daerah Percabangan Pada Sistem Perpipaan. Jurnal Teknologi Terapan, Vol.3, no.1, pp.7-11, 2017.

[7] N. Fuhaid, Pengaruh Sudut Pipa Pesat Terhadap Efisiensi Pembangkit Listrik Tenaga Mikro Hidro. PROTON, Vol. 4, no. 1, pp. 27-32, 2012.

[8] A.Muliawan \& A.Yani, Analisis Daya dan Efisiensi Turbin Air Kinetis Akibat Perubahan Putaran Runner. Journal of Sainstek, Vol.8, no.1, pp.1-9, 2016.

[9] S. O. Anaza1 , M. S. Abdulazeez, Y. A. Yisah , Y. O. Yusuf, B. U. Salawu, S. U. Momoh, Micro Hydro-Electric Energy Generation- An Overview, American Journal of Engineering Research (AJER), Volume-6, Issue-2, pp-05-12, 2017.

[10] A. N. Bilal, Design of Micro - Hydro - Electric Power Station, International Journal of Engineering and Advanced Technology (IJEAT), Volume-2, Issue-5, pp 39-47, 2013.

[11] H. Kurt and Y. Aslan, Optimization of Power Output of A Micro-Hydro Power Station Using Fuzzy Logic Algorithm, International Journal on Technical and Physical Problems of Engineering (IJTPE), Volume 5, Issue 14 Number 1, pp 138-143, 2013.

[12] S. Warsito, A. Syukur dan A. A Nugroho, Studi Awal Perencanaan Sistem Mekanikal dan kelistrikan Pembangkit Listrik Tenaga Mini Hidro", Seminar Teknik Ketenagalistrikan, Teknik Elektro Fakultas Teknik Universitas Diponegoro, Semarang, 2005.

[13] B .Roshni, and S.M, Ali, Potential of Hydro Power Plant in India and its Impact on Environment, International Journal of Engineering Trends and Technology (IJETT), Volume 10, Number 3, pp114-119, 2014.

[14] M. A. Khan and S. Badshah, Design and Analysis of Cross Flow Turbine for Micro Hydro Power Application using Sewerage Water, Research Journal of Applied Sciences, Engineering and Technology, Volume.8, no.7, pp. 821-828, 2014.

[15] M. Naim dan I. Ristiawan, Rancangan Pembangkit Listrik Tenaga Mikro Hidro Di Kampung Dongi Kecamatan Nuha, Dinamika: Jurnal Ilmiah Teknik Mesin, Vol. 9, No. 2, pp.37-44, 2018.
[16] Arismunandar dan S. Kuwahara, Pembangkitan Dengan Tenaga Air, Buku Pegangan Teknik Tenaga Listrik, Jilid I, Jakarta, Pradnya Paramita, 1974.

[17] Arismunandar, Penggerak Mula Turbin, Bandung, ITB Bandung, 1977.

[18] F. DIETZEL dan D. Sriyono, "Turbin Pompa dan Kompresor" Erlangga, Jakarta, 1990. 